\title{
Problem-based Learning Teaching Method Applied to Pharmaceutical Engineering Experiment Teaching Based on the Outcome-based Education Theory
}

\author{
Chengjun Jiang ${ }^{1}$, Guilin Cheng ${ }^{2, *}$ \\ ${ }^{1}$ School of Biological and Chemical Engineering, Zhejiang University of Science and Technology, Hangzhou, CHINA. \\ ${ }^{2}$ Academy of Chinese Medical Sciences, Zhejiang Chinese Medical University, Hangzhou, CHINA.
}

\begin{abstract}
Objectives: Pharmaceutical engineering experiments are among the most important links in teaching of the pharmaceutical engineering specialty. This study aimed to reform the content of the experiment course for the pharmaceutical engineering specialty under the guidance of the outcome-based education (OBE) theory. Materials and Methods: We reformed the teaching content and methods of the pharmaceutical engineering experiment course at Zhejiang University of Science and Technology by using problembased learning (PBL) teaching method and established a scientific evaluation system based on the PBL teaching method. Results: In the process of teaching implementation, the chosen approach stimulated students' enthusiasm for learning, exerted their subjective initiative, improved their ability to use the knowledge comprehensively to analyze and solve problems, enhanced their ability to think critically and promoted the training of their innovation awareness, solidarity, cooperation consciousness and scientific spirit.
\end{abstract}

Key words: Outcome-based education, Problem-based learning, Pharmaceutical engineering experiment, Evaluation system.

\section{INTRODUCTION}

Created by William G. Spady, 'outcomebased education (OBE) means clearly focusing and organizing everything in an educational system around what is essential for all students to be able to do successfully at the end of their learning experiences'. Also known as results-oriented education, this approach requires planners to identify the skills imperative for students in their current professional field, establish the knowledge and abilities necessary after graduation and design teaching goals and tasks accordingly. ${ }^{2}$ Under the guidance of this concept, the design of the content of experimental lessons has changed from subject-based to based on student employment and development needs. The basic requirements of experimental teaching relating to the pharmaceutical engineering specialty are to a) master the basic knowledge, theory and skills of the pharmaceutical engineering specialty; b) possess drug design and development capabilities; c) embody the sense of innovation, safety awareness, environmental protection awareness and sustainable development concepts; d) be able to use computer and information technology to obtain, process and use pharmaceutical and subject-related information; e) have text and oral expression, communication, coordination and teamwork capabilities, ${ }^{3}$ and $f$ ) have the ability to adapt to future science and technology, as well as to social and economic development. ${ }^{4,5}$ To make it possible to achieve these requirements, a comprehensive experiment was set up based on the OBE theory through the problembased learning (PBL) teaching method. While students' autonomous learning was the main feature of the experiment, relevant conditions and atmospheres were carefully
Submission Date: 20-02-2020; Revision Date: 29-06-2020; Accepted Date: 09-09-2020

DOI: 10.5530/ijper.55.1.8 Correspondence: Prof. Guilin Cheng Academy of Chinese Medical Sciences, Zhejiang Chinese Medical University, Hangzhou-311402, CHINA. Phone: $+86-571-61768510$ Email id: cheng_guilin@163. com

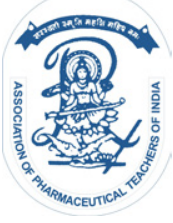

www.ijper.org 
designed to meet and adapt to the diversity of students' learning styles and needs. Along with this, we reformed the management mode of experimental teaching: the experimental form of instructing students to complete a fixed content within a fixed time has been changed to a flexible experimental mode. During the comprehensive experiment, students were able to set the experiment time and use the test equipment in advance according to their own schedule and experimental progress.

\section{MATERIALS AND METHODS}

\section{Teaching Content Design}

Guided by the OBE theory, we believe that comprehensive experimental content should be cuttingedge and systematic, in addition to encompassing safety, environmental protection, green design and other related topics. Students must conduct experiments in small groups and process data collectively using experimental software properly. Therefore, in the design and practice of experiments, research-oriented issues should be implemented to reflect the scientificity, innovation and openness of teaching content. To base the teaching content design, we chose a scientific research project from our group entitled 'Study on Extraction and Identification of Curcumin'.

\section{Implementation Process of the PBL Teaching Method}

As shown in Table 1, the PBL teaching plan and goals were set up first. The tutoring preparation period was one week before the beginning of the course. Teachers taught tutorial classes, clearly informed students about specific experimental purposes, requirements and goals and required each group of students to search, analyze and summarize relevant literature, to formulate at least two detailed experimental plans and to prepare PowerPoint presentations (PPTs) to prepare for classes. Before preparing the reports, the groups prepared for the first day after tutorial classes. The groups adopted 10-min PPTs to report experimental plans and assumptions to teachers and students, which must include any difficulties encountered, the solution to the plan and the feasibility study. After each presentation, members of other groups asked questions that were responded jointly by the presenting group. If the group in question could not answer or was unsure of the answer to the difficult questions, the teacher would give tips and guidance. The content of experimental classroom teaching focused on the rigorous operation of each group of students based on their experimental schemes, careful and comprehensive observation, detailed recording of real phenomena and accurate data and comprehensive characterization tests. At the same time, students were required to pay special attention to the development of safety, health, environmental protection, scientific spirit, academic ethics and other consciousness. Teachers observed the operation of each group of students, corrected any unreasonable operations by students at all times, explored experimental phenomena and asked questions. After the entire experiment was completed, each group conducted data processing and analysis collectively and each student independently wrote a paper-style scientific experiment report. Then, each group produced a PPT and developed a summary, including reports, questions and teacher comments. Based on their experiments, the students held academic exchanges, made posters, selected the keynote members of the respective groups and acted effectively as researchers. They exchanged their academic achievements, shared and interacted and improved together. The most important gains in this process were the improvement of critical thinking and the acquisition of the ability to organize and communicate. Finally, a questionnaire was distributed among students to fully understand their feelings and experiences, in order to further improve teaching.

\section{Evaluation System Based on the PBL Teaching Method}

Traditional assessment methods place too much emphasis on the accuracy and precision of test results and the writing of experimental reports; ${ }^{7}$ they focus too much on the evaluation of experimental results and ignore the innovative consciousness and comprehensive quality of students. Based on the OBE philosophy, we believe that a reform of the assessment method is paramount. The definition of assessment indicators should consider not only the basic knowledge and skills involved in the students' experiments and their ability to write experimental reports, but also the investigation of the development of experimental literacy and ability and the achievement of both process and emotional goals (Table 2). Considering the course characteristics of comprehensive experiments, first, we examined the design of students' experimental schemes and their ability to select experimental methods with a special focus on encouraging the embodied innovative, green environmental protection and safety consciousness. Second, we examined the operating skills of student's especially encouraging self-study of instruments and how to use the equipment; once again, we were required to pay attention to the writing and expression of the experimental report. We had to verify not only 


\begin{tabular}{|c|c|c|c|c|}
\hline Teaching stage & Teaching content & Topics included & Teaching method & $\begin{array}{l}\text { Basic requirements/teaching } \\
\text { goals }\end{array}$ \\
\hline \multirow{3}{*}{$\begin{array}{l}\text { Experiment } \\
\text { preparation stage } \\
\text { (one week) }\end{array}$} & $\begin{array}{l}\text { Experimental objectives } \\
\text { and design requirements }\end{array}$ & $\begin{array}{l}\text { Basic concepts, } \\
\text { safety common } \\
\text { sense, environmental } \\
\text { protection concepts, } \\
\text { green solutions }\end{array}$ & Teacher lecture & \multirow{2}{*}{$\begin{array}{l}\text { Strengthen basic knowledge and } \\
\text { theories, establish awareness on } \\
\text { safety and environmental protection } \\
\text { and improve the ability to obtain } \\
\text { and process information }\end{array}$} \\
\hline & $\begin{array}{l}\text { Master the principles of } \\
\text { the experiment and make } \\
\text { a list of the reagents and } \\
\text { instruments used }\end{array}$ & $\begin{array}{l}\text { Basic theory, reagent } \\
\text { properties and } \\
\text { instrument operation } \\
\text { method }\end{array}$ & $\begin{array}{l}\text { Students self- } \\
\text { study and } \\
\text { discussion }\end{array}$ & \\
\hline & $\begin{array}{l}\text { Design at least two } \\
\text { protocols per team }\end{array}$ & $\begin{array}{l}\text { Literature search, } \\
\text { comprehensive use of } \\
\text { knowledge to formulate } \\
\text { solutions to problems, } \\
\text { evaluation of feasibility } \\
\text { and prediction effect }\end{array}$ & $\begin{array}{l}\text { Students' } \\
\text { independent } \\
\text { design, display } \\
\text { and program } \\
\text { evaluation }\end{array}$ & $\begin{array}{l}\text { Training in drug design and } \\
\text { development, embodying a sense } \\
\text { of innovation and improving oral } \\
\text { expression and communication } \\
\text { skills }\end{array}$ \\
\hline \multirow{6}{*}{$\begin{array}{c}\text { Experiment } \\
\text { implementation } \\
\text { stage (two weeks) }\end{array}$} & $\begin{array}{l}\text { Extraction and purification } \\
\text { of curcumin from different } \\
\text { raw materials using } \\
\text { different techniques }\end{array}$ & $\begin{array}{l}\text { Isolation and } \\
\text { purification of } \\
\text { substances }\end{array}$ & \multirow{5}{*}{$\begin{array}{c}\text { Students } \\
\text { complete } \\
\text { experiments } \\
\text { independently and } \\
\text { teachers provide } \\
\text { the necessary } \\
\text { help }\end{array}$} & \multirow{5}{*}{$\begin{array}{l}\text { Strengthen basic skills, establish } \\
\text { environmental awareness } \\
\text { and sustainable development } \\
\text { concepts, abide by academic } \\
\text { ethics and professional norms, } \\
\text { have a scientific spirit and improve } \\
\text { coordination and teamwork } \\
\text { capabilities }\end{array}$} \\
\hline & $\begin{array}{l}\text { Preparation of compound } \\
\text { curcumin in different } \\
\text { dosage forms }\end{array}$ & $\begin{array}{c}\text { Preparation of } \\
\text { pharmaceutical dosage } \\
\text { forms }\end{array}$ & & \\
\hline & $\begin{array}{l}\text { Determination of the } \\
\text { melting point and content } \\
\text { of curcumin }\end{array}$ & \multirow{3}{*}{$\begin{array}{l}\text { Qualitative and } \\
\text { quantitative analysis } \\
\text { and characterization } \\
\text { of materials, } \\
\text { determination of } \\
\text { physical quantities and } \\
\text { chemical properties, } \\
\text { safe and correct } \\
\text { use of chemicals } \\
\text { and instruments, } \\
\text { scientific and } \\
\text { standardized recording } \\
\text { of experimental } \\
\text { phenomena and } \\
\text { data, judgment of the } \\
\text { rationality and accuracy } \\
\text { of data and three waste } \\
\text { disposals }\end{array}$} & & \\
\hline & $\begin{array}{l}\text { Curcumin Properties } \\
\text { Experiment }\end{array}$ & & & \\
\hline & $\begin{array}{l}\text { Compare the effect of } \\
\text { curcumin formulations } \\
\text { on the release and } \\
\text { absorption in vivo }\end{array}$ & & & \\
\hline & $\begin{array}{l}\text { Data processing } \\
\text { and completion of } \\
\text { experimental reports }\end{array}$ & $\begin{array}{l}\text { Use of the database } \\
\text { to search and review } \\
\text { relevant Chinese and } \\
\text { English literature. Use } \\
\text { of the ChemDraw and } \\
\text { Oringin software. }\end{array}$ & $\begin{array}{l}\text { Students process } \\
\text { data collectively } \\
\text { and write } \\
\text { experimental } \\
\text { reports } \\
\text { independently }\end{array}$ & $\begin{array}{l}\text { International vision and ability } \\
\text { to communicate across cultures } \\
\text { using computers and information } \\
\text { technology to acquire, process and } \\
\text { use information and words }\end{array}$ \\
\hline \multirow{2}{*}{$\begin{array}{c}\text { Experiment summary } \\
\text { stage } \\
\text { (one week) }\end{array}$} & $\begin{array}{l}\text { Lesson Experience } \\
\text { Communication }\end{array}$ & \multirow{2}{*}{$\begin{array}{l}\text { Good verbal or written } \\
\text { communication }\end{array}$} & $\begin{array}{l}\text { Student } \\
\text { exchanges } \\
\text { and teacher } \\
\text { comments }\end{array}$ & \multirow{2}{*}{$\begin{array}{l}\text { Improve oral expression and } \\
\text { communication skills }\end{array}$} \\
\hline & $\begin{array}{l}\text { Poster presentation and } \\
\text { academic conference }\end{array}$ & & $\begin{array}{l}\text { Student lectures } \\
\text { and questions } \\
\text { exchange }\end{array}$ & \\
\hline $\begin{array}{l}\text { evaluation: } \\
\text { to learn inc }\end{array}$ & $\begin{array}{l}\text { gh self-study and self-d } \\
\text { idently and to develop tl } \\
\text { elopment. }\end{array}$ & ed experiments and & $\begin{array}{l}\text { pletion of the entir } \\
\text { better adapt to the }\end{array}$ & $\begin{array}{l}\text { research process, students acquire } \\
\text { uture of science and technology }\end{array}$ \\
\hline
\end{tabular}


Table 2: Experimental evaluation system and weight table.

\begin{tabular}{|c|c|c|c|c|}
\hline Evaluation object & $\begin{array}{l}\text { First-level } \\
\text { indicators }\end{array}$ & $\begin{array}{l}\text { Secondary } \\
\text { indicators }\end{array}$ & Main observation point & $\begin{array}{l}\text { Reference } \\
\text { weight }\end{array}$ \\
\hline \multirow{5}{*}{$\begin{array}{l}\text { Mutual evaluation } \\
\text { among team } \\
\text { members }(40 \%)\end{array}$} & \multirow{5}{*}{ 1. Contribution } & 1.1 Literature & $\begin{array}{l}\text { - Number of documents consulted } \\
\text { - Accuracy of the literature and its contribution to } \\
\text { the design of the scheme }\end{array}$ & 5 \\
\hline & & 1.2 Design & $\begin{array}{l}\text { - Preliminary proposal } \\
\text { - Recommendations for performance } \\
\text { characterization } \\
\text { - Characterization methods provided and } \\
\text { recommendations for the use of instruments }\end{array}$ & 10 \\
\hline & & $\begin{array}{l}1.3 \text { Group } \\
\text { discussion }\end{array}$ & $\begin{array}{l}\text { - Actively asking questions } \\
\text { - Actively seeking answers and solving problems }\end{array}$ & 10 \\
\hline & & $\begin{array}{l}1.4 \text { Experimental } \\
\text { operation }\end{array}$ & $\begin{array}{l}\text { - The workload involved in participating in the } \\
\text { experiment } \\
\text { - Correct operation } \\
\text { - Security awareness }\end{array}$ & 10 \\
\hline & & $\begin{array}{l}1.5 \text { Summary } \\
\text { report }\end{array}$ & $\begin{array}{l}\text { - Participate in data analysis and calculate } \\
\text { correctly } \\
\text { - Participate in analytical discussions and give } \\
\text { opinions } \\
\text { - Participate in the production and reporting of } \\
\text { PPTs }\end{array}$ & 5 \\
\hline \multirow{4}{*}{ Peer review (20\%) } & \multirow{4}{*}{ 2. Achievements } & $\begin{array}{l}2.1 \mathrm{PPT} \\
\text { preparation }\end{array}$ & $\begin{array}{l}\text { - PPT beautifully designed and closely linked to } \\
\text { the theme } \\
\text { - Clear and logical }\end{array}$ & 5 \\
\hline & & 2.2 Report display & $\begin{array}{l}\text { - Natural manners, loud voice, smooth language } \\
\text { - Clear and accurate report content } \\
\text { - Good report time and rhythm }\end{array}$ & 5 \\
\hline & & $\begin{array}{l}2.3 \text { Answer } \\
\text { question }\end{array}$ & $\begin{array}{l}\text { - Have new ideas or insights } \\
\text { - Concise and standardized }\end{array}$ & 5 \\
\hline & & $\begin{array}{l}2.4 \text { Overall } \\
\text { performance }\end{array}$ & $\begin{array}{l}\text { - Comprehensive information and content } \\
\text { - Good teamwork and active participation of all } \\
\text { members }\end{array}$ & 5 \\
\hline \multirow{4}{*}{$\begin{array}{l}\text { Teacher evaluation } \\
\qquad(40 \%)\end{array}$} & \multirow{4}{*}{$\begin{array}{l}\text { 3. Overall } \\
\text { evaluation }\end{array}$} & $\begin{array}{l}\text { 3.1 Experimental } \\
\text { report }\end{array}$ & $\begin{array}{l}\text { - Comprehensive and novel literature, } \\
\text { summarizing and objectively correct } \\
\text { - Experimental data are authentic and reliable } \\
\text { - Strong systemic and logical } \\
\text { - Clear text expressions, standardized diagrams } \\
\text { and formulas }\end{array}$ & 10 \\
\hline & & $\begin{array}{l}3.2 \text { Overall } \\
\text { evaluation of the } \\
\text { experimental } \\
\text { process }\end{array}$ & $\begin{array}{l}\text { The experimental scheme design is scientific } \\
\text { and feasible and the characterization is } \\
\text { reasonable and comprehensive } \\
\text { - Participate in the experiment throughout the } \\
\text { process and operate carefully } \\
\text { - The two reports and exchanges had clear ideas } \\
\text { and focused points }\end{array}$ & 10 \\
\hline & & 3.3 Critical thinking & $\begin{array}{l}\text { - Ability to think about the experiment itself } \\
\text { - Significant questions to other groups } \\
\text { - Ability to answer questions from other groups } \\
\text { and to respond reasonably }\end{array}$ & 10 \\
\hline & & $\begin{array}{l}3.4 \text { Team } \\
\text { cooperation }\end{array}$ & $\begin{array}{l}\text { - Strong teamwork } \\
\text { Ability to effectively coordinate and cooperate } \\
\text { with other members }\end{array}$ & 10 \\
\hline
\end{tabular}


the students' ability to use the database to retrieve Chinese and English literature, process data and analyze problems, but also their academic ethics and standards. Table 2 shows the comprehensive experimental evaluation index system and the respective weights. First, the group members evaluate each other mainly to check the contribution of each member in the entire experiment process, accounting for $50 \%$ of the evaluation; then, an intergroup evaluation is conducted mainly to check the results of each group, accounting for $20 \%$ of the evaluation; finally, the teacher evaluation takes place mainly assessing the experimental report with teamwork, accounting for $30 \%$ of the evaluation. The instructor can award 1 to 10 extra points for outstanding students according to their specific performance in encouraging innovative design, green environmental protection programs and foreign language communication skills.

\section{RESULTS AND DISCUSSION}

After the completion of each experiment session, a questionnaire survey was conducted in which students summarized the main points in a timely manner and provided feedback for the continuous improvement of specific implementation steps and the pace of teaching. For the third student session, which adopted the PBL teaching method, 60 students $(96.37 \%$ of the total) declared themselves satisfied with the teaching strategies, showing that the course improved considerably. After completing the experiments, the students summarized that it was the first time that they designed an experimental scheme by themselves, operated large instruments to characterize the results of the experiments, analyzed experimental data and participated in academic reports as scientists. They claim to have learned a lot and acquired a lot of knowledge in the process. Although the initial feeling was that it was not difficult to design an experiment, the students pointed out that, in the process of consulting the literature and discussing with the group members, the experimental purpose and the overall goal must be refined and broken down into small goals and a single experimental process. Students also pointed out that the principle needs to be further understood and that there are many parameters for a query. According to them, each test method and instrument operation method must be confirmed and then a detailed experiment plan and a list of reagents and instrument supplies must be formulated. They also consider necessary to confirm and communicate the experimental plan and the division of labor with team members, as well as to communicate the reagents and instruments to the laboratory teachers. In the course of the experiment, one must be able to observe and discover problems at all times and to correct the plan in time to overcome some unforeseen difficulties and achieve the goal efficiently. For students, the most interesting point was the report of the results of their research at academic exchanges. Through this exchange, they were able to see different schemes designed by different groups and obtain different results. Their most profound lesson was that a scientific worker should have a critical spirit. One cannot simply accept the collected information, materials and even experimental data. Selective and skeptical applications must use multiple representations and check the accuracy of the De confirmation results. Then, one can understand the meaning of "bold assumptions, be careful to verify."

The PBL teaching method is problem-oriented. From the preparation stage, students need to target the problem and the task and actively collect data, organize and put forward their views and shift from passive to active learning. In the whole process, students were in groups discussing the problems they face, asking their own questions based on the opinions of others, playing their roles within the team and shifting from individual to cooperative learning. Through this process, students were able to solve the problem step-by-step and their enthusiasm and initiative for learning, cooperation and communication skills gradually enhanced.

The PBL teaching method is also student-centered. Throughout the entire practice, students must bear their main responsibilities by checking data actively, integrating knowledge, participating in experiments and establishing multi-faceted communication with group members and teachers at all times. To achieve a collision of perspectives, this process can mobilize students' sense of participation coupled with autonomous thinking and promote their ability to apply knowledge in practical settings.

Finally, the PBL teaching method focuses on group cooperation. Group members propose different ideas and discuss with each other, which leads students to think autonomously and positively. Based on the extensive collection of evidence and rigorous experiments, students form a chain of evidence to support their own opinions, do not draw conclusions beyond the evidence. In the collision of thought sparks, students must also learn to pay attention to the opinions and reasons of others, consider different ideas and integrate views intuitively. This process improved students' ability to analyze and systematically organize problems and ideas. 


\section{CONCLUSION}

Under the guidance of the OBE theory, this study reformed the comprehensive experimental content of the pharmaceutical engineering specialty and implemented the PBL teaching method, thereby achieving positive teaching results. The four elements of a successful reform are changing educational concepts, changing the role of teachers, rationally dividing experimental groups and establishing a scientific evaluation system. In the process of teaching implementation, students' enthusiasm for learning was effectively stimulated, students' subjective initiative was brought into play, students' ability to use knowledge to analyze and solve problems was improved, students' ability to think critically was developed and students' creative awareness was fostered. The development of a sense of unity and cooperation and of a scientific spirit has reached the training goal of the pharmaceutical engineering experimental course. As a result, the course provides students with a solid understanding of the operational skills required for drug preparation, trains students to develop the ability to analyze the actual problems involved in drug production and ensured the cultivation of high-quality scientific and technological talents in the pharmaceutical industry.

\section{ACKNOWLEDGEMENT}

We thank the students who participated in the study for their cooperation. This work was supported by the Zhejiang Province Basic Public Welfare Research Project (LGJ20B060001).

\section{CONFLICT OF INTEREST}

The authors declare no conflicts of interest.

\section{ABBREVIATIONS}

PBL: Problem-based learning; OBE: Outcome-based education; PPT: PowerPoint.

\section{REFERENCES}

1. Spady WG. Outcome-Based Education: Critical Issues and Answers. Arlington, VA: American Association of School Administrators. 1994;1-10.

2. Liu Z, Lin Y, Zhong Z. Preliminary Evaluation of a Reform of Methods to Teach Pharmaceutical Polymer Materials Science to a Class of Diverse Majors. Indian J of Pharmaceutical Education and Research. 2019;53(4):613-9.

3. Zhao F, Yu Y, Ren S, Liu S, Rong X. Improving the Practical Education of Chemical and Pharmaceutical Engineering Majors in Chinese Universities. Journal of Chemical Education. 2014;91(2):211-5.

4. Li H, Shi X. Calculating and Evaluating of the Achievements of Pharmaceutical Separation Engineering Course for Pharmaceutical Engineering Major Based on Engineering Education Certification. Indian J of Pharmaceutical Education and Research. 2020;54(1):17-21.

5. Li H, Wang XM, Hu GQ. Research on Grading Method of Courses Based on Engineering Professional Certification. International Education and Research Journal. 2018;4(11):8-10.

6. Cheng GL, Deng CY, Jiang CJ. Research on Solubility Products of Curcumincatechol Co-crystal. Chinese Journal of Modern Applied Pharmacy. 2018;35(5):623-7

7. El-Magboub A, Haworth IS, Sutch BT, Romero RM. Evaluation of inclass and Online Discussion Meetings in a Biopharmaceutics Problembased Learning Class [J]. Currents in Pharmacy Teaching and Learning. 2016;8(6):811-20

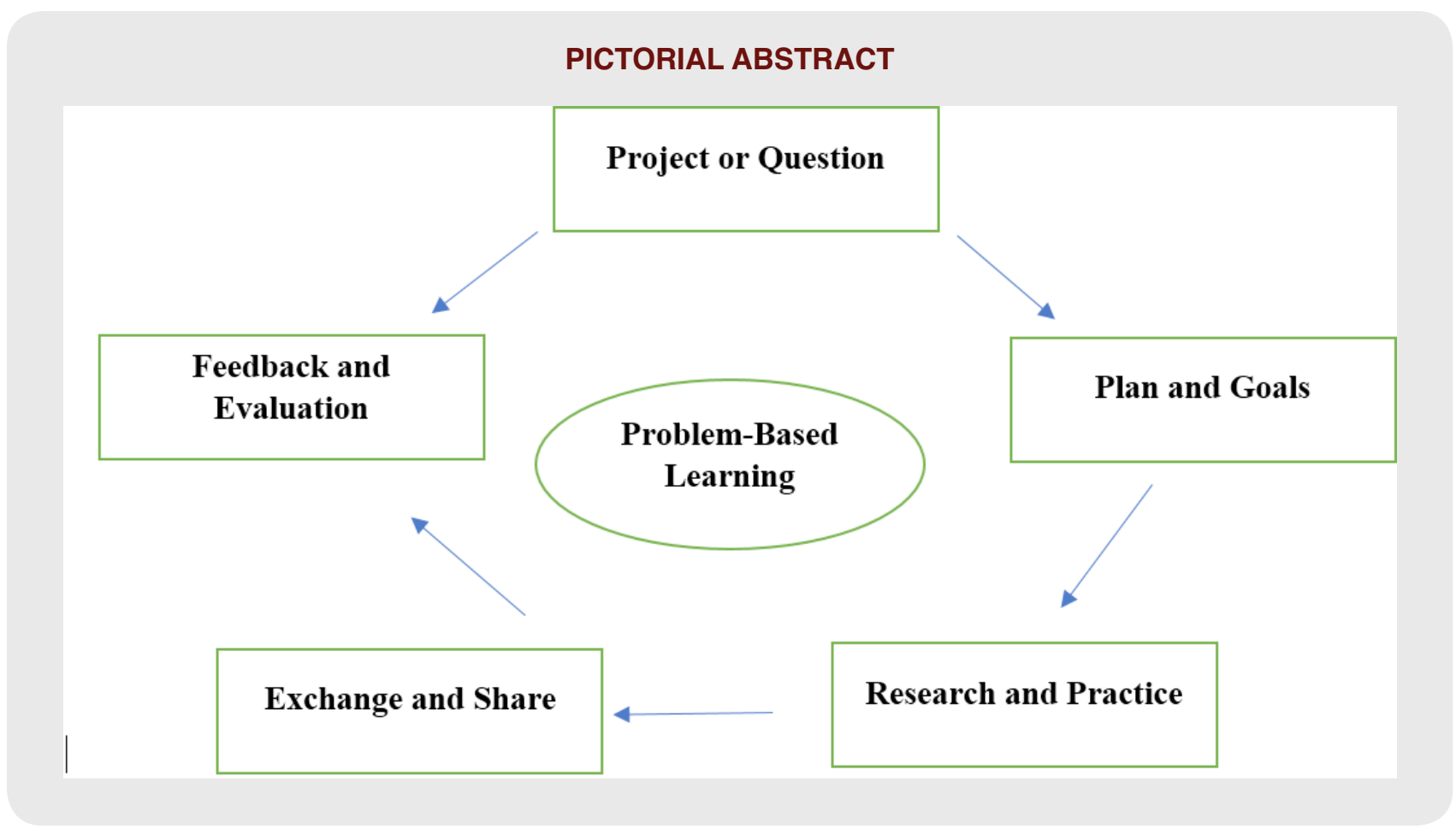




\section{SUMMARY}

Problem-based learning teaching method applied to pharmaceutical engineering experiment teaching based on the outcome-based education theory improves student's ability to use knowledge comprehensively to analyze and solve problems, enhances their ability to think critically and promotes the training of their innovation awareness, solidarity, cooperation consciousness and scientific spirit.

\section{About Authors}

Dr. Chengjun Jiang, Associate Professor, School of Biological and Chemical Engineering, Zhejiang University of Science and Technology, He is actively involved in researches of Pharmaceutical engineering Education, published more than 30 research papers in various national and international journals.

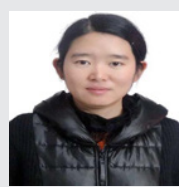

Dr. Guilin Cheng, Associate Professor, Academy of Chinese Medical Sciences, Zhejiang Chinese Medical University. She is actively involved in research and teaching of Traditional Chinese Medicine.

Cite this article: Jiang C, Cheng G. Problem-based Learning Teaching Method Applied to Pharmaceutical Engineering Experiment Teaching Based on the Outcome-based Education Theory. Indian $\mathrm{J}$ of Pharmaceutical Education and Research. 2021;55(1):56-62. 